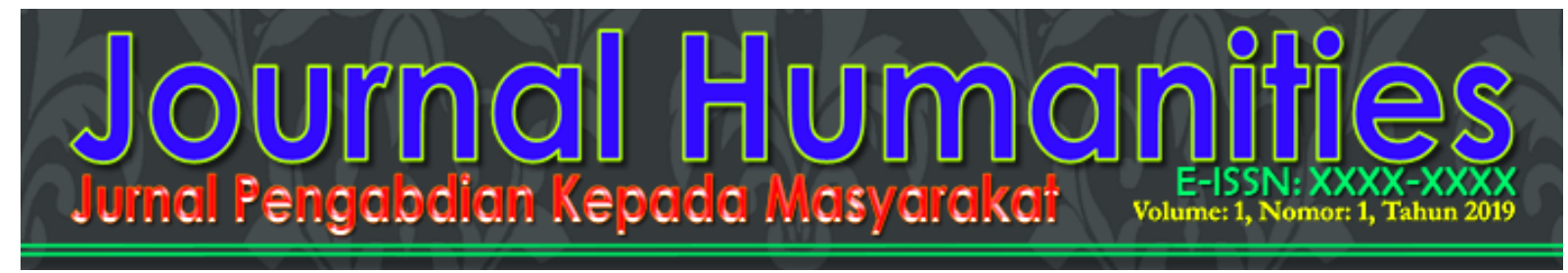

\title{
IMPLEMENTATION OF BASIC MOTION LEARNING AND USE OF TEST INSTRUMENT OF GROSS MOTOR DEVELOPMENT (TGMD) IN EVALUATING BASIC MOTION SKILLS
}

\author{
Oktarifaldi $^{1}$, Risky Syahputra ${ }^{2}$, Hasriwandi Nur ${ }^{3}$, Willadi Rasyid ${ }^{4}$ \\ ${ }^{1234}$ Program Studi Pendidikan Jasmani Kesehatan dan Rekreasi, Fakultas Ilmu Keolahragaan, \\ Universitas Negeri Padang. Jalan Prof. Dr. Hamka Air Tawar Barat, Padang, 25132, Indonesia. \\ oktarifaldi88@fik.unp.ac.id ${ }^{1}$, risky@ fik.unp.ac.id ${ }^{2}$, hasriwandi.nur@ fik.unp.ac.id ${ }^{3}$.willadi@ fik.unp.ac.id ${ }^{4}$
}

Abstract

UNESCO reports that the implementation of PAUD in Indonesia places great importance on academic content such as writing, arithmetic and reading and provides very little opportunity to actively play physically with children. Research shows that physical activity of children at an early age will greatly trigger the development of cognitive abilities. Based on observations and studies in the field, it was found that almost all teachers and educators in PAUD Sijunjung district did not have the insight and skills in measuring and evaluating the basic movements of children. Based on research, basic motion cannot develop naturally but must be taught correctly and continuously. This community service activity for partners aims to: (a) find out the importance of basic motion, (b) have skills in practicing basic early childhood movements, (c) be able to use instruments to measure basic movement skills in early childhood. The method used uses the principle that every innovation received by PAUD teachers through PIE (Preparation, Implementation and Evaluation). This means that the delivery of innovations to Partners is carried out through the stages of explanation, discussion, practice as well as the evaluation phase with assistance in the learning process. The results of the training obtained by partners as participants can be described as follows: (a) Having insight and understanding of the importance of basic movement skills, (b) having experience in practicing basic motion skills, (c) knowing and having the ability to use basic motion skills test instruments.

Key Words : Basic Motion, TGMD Instruments, PAUD Teachers

\section{IMPLEMENTASI PEMBELAJARAN GERAKAN DASAR DAN PENGGUNAAN UJI INSTRUMEN PENGEMBANGAN MOTOR GROSS (TGMD) DALAM MENGEVALUASI KETERAMPILAN GERAKAN DASAR}

\begin{abstract}
Abstrak
UNESCO melaporkan pelaksanaan PAUD di Indonesia sangat mengutamakan konten akademik seperti menulis, berhitung, dan membaca serta sangat kurang memberikan kesempatan aktif bermain secara fisik pada anak. Riset membuktikan bahwa aktifitas fisik anak pada usia dini akan sangat memicu perkembangan kemampuan kognitif. Berdasarkan observasi dan studi di lapangan, ditemui hampir seluruh guru dan tenaga pendidik di PAUD kabupaten Sijunjung belum memiliki wawasan dan keterampilan dalam mengukur serta mengevaluasi gerak dasar anak. Berdasarkan penelitian, gerak dasar tidak dapat berkembang dengan alami melainkan harus diajarkan secara benar dan kontiniu. Kegiatan pengabdian kepada masyarakat ini bagi mitra bertujuan untuk: (a) mengetahui pentingnya gerak dasar, (b) memiliki keterampilan dalam mempraktekkan gerak dasar anak usia dini, (c) mampu menggunakan instrument untuk mengukur keterampilan gerak dasar anak usia dini. Metode yang dilakukan menggunakan prinsip bahwa setiap inovasi yang diterima oleh guru PAUD melalui PIE (Preparation, Implementation and Evaluation). Penyampaian inovasi kepada Mitra ditempuh melalui tahapan penjelasan, diskusi, praktek serta evaluasi dan pendampingan dalam pembelajaran. Hasil pelatihan yang diperoleh mitra sebagai peserta dapat dideskripsikan sebagai berikut: (a) Memiliki wawasan dan pemahaman tentang pentingnya keterampilan gerak dasar, (b) memiliki pengalaman dalam
\end{abstract}

1 | Implementation Of Tgmd In Evaluating Basic Motion Skills Oktarifaldi $^{1}$, Risky Syahputra ${ }^{2}$, Hasriwandi Nur ${ }^{3}$, Willadi Rasyid ${ }^{4}$ http://jha.ppj.unp.ac.id 


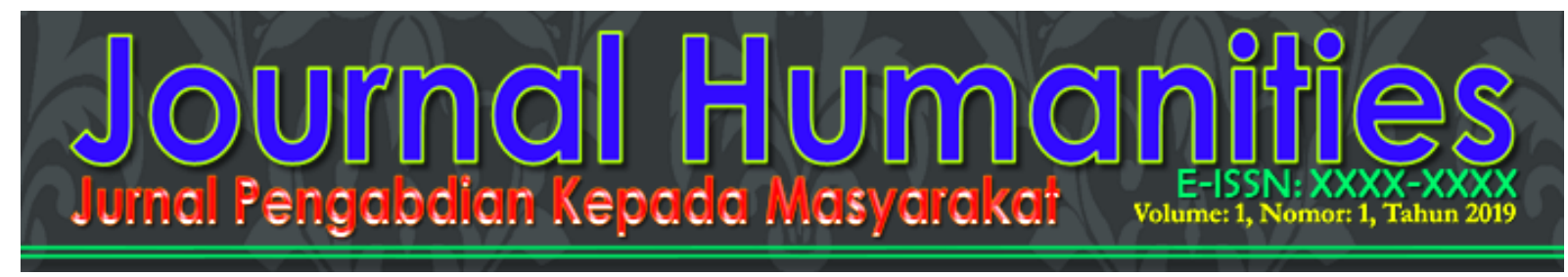

mempraktekkan keterampilan gerak dasar, (c) mengetahui dan memiliki kemampuan menggunakan instrument tes keterampilan gerak dasar.

Kata Kunci: Gerak Dasar, Instrumen TGMD, Guru PAUD

\section{ANALISIS SITUASI}

Pendidikan usia dini merupakan periode yang penting dan perlu mendapat penanganan sedini mungkin. Usia dini merupakan "golden age", dimana periode ini merupakan fondasi perkembangan kesehatan fisik, fungsi kognitif, interaksi sosial, dan hubungan emosional. Penelitian menunjukkan bahwa fase kehidupan awal seorang anak memiliki konsekuensi untuk masa dewasa mereka. Dengan demikian diharapkan penanganan dalam pendidikan anak usia dini harus benar-benar dilakukan dengan serius berdasarkan undang-undang dan peraturan pemerintah secara syah. UNESCO melaporkan, dimana pelaksanaan PAUD di Indonesia sangat mengutamakan konten akademik seperti menulis, berhitung, dan membaca, dan sangat kurang memberikan kesempatan aktif bermain secara fisik pada anak.

Padahal, sesuai dengan teori perkembangan kognitif Piaget, perkembangan kognitif anak usia dini dipengaruhi oleh perkembangan keterampilan motorik, dan begitu juga sebaliknya. Dengan demikian, anak usia dini seharusnya belajar melalui eksplorasi lingkungan yang mensyaratkan mereka lebih banyak bergerak secara aktif. Berdasarkan temuan ini, maka tidaklah heran jika PAUD di Indonesia masih belum mampu mewujudkan pencapaian motorik kasar pada anak dikarenakan anak lebih banyak pasif dan fokus pada konten akademik.

Usia dini dikenal juga dengan "prime time" untuk tumbuh dan kembang otak anak. Anak usia dini merupakan usia ideal untuk mengembangkan dan melakukan berbagai macam aktifitas gerak mulai dari gerak dasar untuk mempersiapkan dirinya melakukan keterampilan gerak spesialisasi saat masa sekolah dan pada cabang olahraga tertentu. Gerak dasar merupakan kecakapan yang membentuk dasar dalam merealisasikan gerak yang benar. Keterampilan gerak dasar dibutuhkan dalam upaya membangun pola gerak secara kompleks dan harus mulai dikembangkan sejak usia dini yakni ketika dia mulai bergerak sesuai dengan keinginanya (Clark dan Metcalve, 2002; Haywood dan Getchell, 2009; Seefeldt, 1980). Stodden et al., (2008) menyarankan gerak dasar harus dilakukan baik itu pada anak-anak, remaja dan dewasa sebagai proses utama yang akan mempengaruhi kemampuan aktivitas fisik.

Dengan demikian jika gerak dasar diajarkan ke pada anak tentunya gerakan olahraga yang kompleks juga akan dikuasai dengan baik. Belum baiknya keretampilan gerak yang ditemui di lapangan, dikarenakan guru belum memiliki wawasan dan keterampilan dalam mengajarkannya. Oleh sebab itu banyaknya anak beraktifitas fisik secara benar yang menurut ahli merupakan fondasi dalam pengembangan kognitif anak hanya sekedar teori dan belum terealisasi di sekolah. Gerak dasar seharusnya sudah diajarkan pada lingkungan pendidikan akan tetapi penelitian membuktikan, guru PAUD di Indonesia masih belum dipersiapkan untuk menerapkan pembelajaran gerak dasar, bahkan sebahagian besar guru PAUD di Sumatera Barat belum memiliki pengetahuan, wawasan dan keterampilan tentang materi gerak dasar, (Bakhtiar \& Famelia 2017).

Sebagai tim penatar dan pemateri pembelajaran gerak dasar anak usia dini, pengabdi juga mendapatkan informasi langsung dari guru-guru pada seminar guru PAUD se Sumatera Barat. Mereka membenarkan keterampilan gerak dasar belum terealisasi pada anak usia dini karena guru PAUD belum memiliki wawasan dan keterampilan untuk mengajarkannya. Kemampuan gerak dalam dalam keterampilan gerak dasar (fundamental motor skill) menggambarkan derajat penguasaan keterampilan dalam menggunakan jari-jari tangan, koordinasi mata-tangan dan mata-kaki, tempo-keseimbangan, serta persepsi visual. (Robinson, et al 2006). Kembali ditegaskan bahwa kurangnya pemahaman tenaga pendidik PAUD akan perkembangan gerak dasar dan metoda pengajarannya juga berperan besar dalam tidak tercapainya standar perkembangan motorik anak.

Pelaksanaan kegiatan program pengabdian kepada masyarakat ini dilakukan berdasarkan temuan penelitian terdahulu serta studi dan observasi yang langsung pengabdi lakukan diberbagai kota dan kabupaten di Sumatera Barat. Terfokus di kabupaten Sijunjung, ditemui permasalahan sebagai 


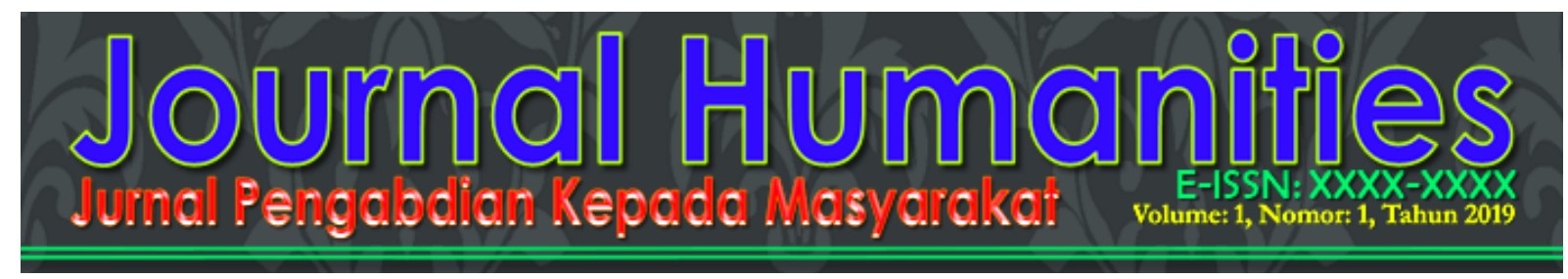

berikut : (a) Sebagian besar guru-guru PAUD di Kabupaten Sijunjung belum memahami bahkan belum mengenal gerak dasar. (b) Sebagian besar guru-guru PAUD di Kabupaten Sijunjung belum memamahami pentingnya gerak dasar bagi anak usia dini. (c) Guru-guru PAUD di Kabupaten Sijunjung belum memiliki keterampilan dalam mempraktekkan gerak dasar. (d) Guru-guru PAUD di Kabupaten Sijunjung belum mengetahui alat ukur dan instrument tes yang digunakan untuk mengetahui tingkat keterampilan gerak dasar serta cara mengevaluasinya.

Berdasarkan kondisi serta situasi tersebut, untuk mengejar ketertinggalan bagi guru-guru PAUD yang telah berada di lapangan khususnya di sekolah tempat tugas masing-masing penulis ingin mengadakan suatu sosialisasi tentang pemahaman tentang materi gerak dasar serta cara mengimplementasikan dalam pengajaran kepada peserta didik di PAUD.

Setelah memahami dan memiliki wawasan kegiatan selanjutnya pengabdi akan melanjutkan dengan bimbingan dalam mengevaluasi keterampilan gerak dasar anak yang selanjutnya guru juga mampu merancang pembelajaran gerak dasar. Hal ini akan pengabdi wujudkan melalui pelatihan yang dilakukan kepada guru PAUD dan TK di Kabupaten Sijunjung.

Fokus kegiatan adalah melatih guru untuk : (a) Memiliki wawasan dan pemahaman tentang pentingnya keterampilan gerak dasar bagi anak usia dini, (b) memiliki pengalaman dalam mempraktekkan keterampilan gerak dasar anak usia dini (c) mengetahui dan memiliki kemampuan merealisasikan instrument tes keterampilan gerak dasar, (d) mampu merancang pembelajaran gerak dasar dan merealisasikannya di tempat tugas masing-masing secara efektif dan kontiniu.

\section{SOLISI DAN TARGET}

Jika ditelaah, komponen motorik kasar dalam Permendiknas No.58 tahun 2009 ternyata belum mencakup seluruh keterampilan gerak dasar yang semestinya dimiliki oleh anak usia dini. Sementara itu, keterampilan gerak dasar ini sangat penting dalam tumbuh kembang anak. Perkembangan gerak dasar menurut Ulrich (2000) sering diabaikan oleh para pendidik pada awal masa kanak-kanak. Goodway dalam Sciencedaily (2010) menyatakan "banyak orang bahkan tenaga pendidik meyakini bahwa keterampilan gerak dasar berkembang secara alami, namun banyak studi yang kami lakukaan menunjukkan tidaklah demikian.

Hasil penelitian yang telah dilakukan oleh Universitas MacMaster Kanada, menemukan bahwa anak yang lebih sering melakukan aktivitas fisik memiliki tingkat kemampuan gerak yang lebih baik, sebaliknya anak yang hanya melakukan aktivitas fisik beberapa kali saja dalam seminggu memiliki tingkat kemampuan gerak dasar yang lebih rendah pula (McMaster University, Kanada., 2011). Menurut Gallahue (2012) ketrampilan gerak dasar dikelompokkan atas tiga bagian, yaitu: (1) ketrampilan lokomotor, dan (2) ketrampilan keseimbangan dan (3) kerampilan manipulatif. Gusril (2015) menerangkan gerak dasar utama merupakan pola gerak yang inherent yang membentuk dasardasar untuk gerak-gerak terampil yang kompleks dan khas meliputi : (1) gerak-gerak lokomotor, (2) gerak non lokomotor, (3) gerak manipulative.

Dengan demikian, perkembangan gerak dasar mencakup pembangunan perilaku gerakan yang digunakan untuk memindahkan tubuh dari satu tempat ke tempat lain (locomotor) dan menerima atau mengirim suatu benda atau objek (object control). Menurut Gallahue, Ozmun dan Goodway (2012), keterampilan gerak dasar yang sangat penting bagi anak usia dini terbagi atas dua bentuk, yaitu lokomotor dan objek kontrol.

Berdasarkan observasi, banyak tenaga pengajar di TK dan PAUD kurang memperhatikan aktifitas fisik secara kuantitas dan kualitas, sehingga kondisi yang ditemui di lapangan seperti di PAUD atau Play Group, anak-anak diberikan waktu bermain, namun kurang memperhatikan aspek keterampilan gerak dasar anak. Padahal, kegagalan dalam melakukan keterampilan gerak dasar ini, akan berpengaruh tidak saja pada kemampuan gerak anak, tapi juga terkait langsung pada kepribadian dan kemampuan kognitif anak. Untuk menyikapi hal ini, program pengembangan keterampilan gerak dasar merupakan dasar dari keberhasilan dan kesehatan serta kesegaran jasmani anak disepanjang hidupnya.

Kesalahan dalam pelaksanaan gerak dasar saat usia dini akan bersifat permanen hingga dewasa, sehingga akan menimbulkan gangguan saat melakukan aktifitas sehari-hari, yang lama

\section{3 | Implementation Of Tgmd In Evaluating Basic Motion Skills Oktarifaldi $^{1}$, Risky Syahputra ${ }^{2}$, Hasriwandi Nur ${ }^{3}$, Willadi Rasyid ${ }^{4}$ \\ http://jha.ppj.unp.ac.id}




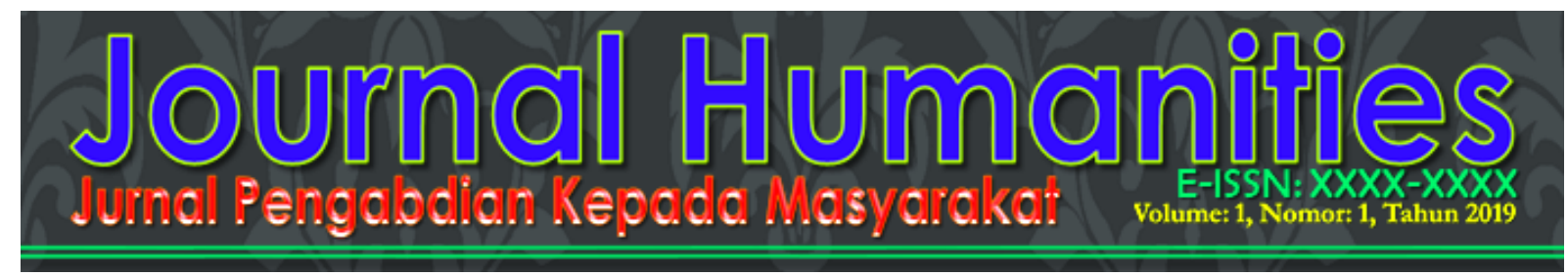

kelamaan, gangguan ini akan menjadi keluhan rasa sakit. Efek negatif ini bisa timbul dalam waktu singkat atau setelah anak menjadi manusia dewasa. Untuk menghindari hal ini tentunya anak sejak dari dini harus dibekali dengan keterampilan gerak dasar yang baik. Realisasi gerak dasar yang seharusnya sudah diterapkan di sekolah-sekolah terutama di TK atau PAUD belum berjalan dengan baik bukanlah kesalahan dari guru dan tenaga pendidik semata.

Pada tingkat LPTK misalnya, observasi yang dilakukan ke kampus dan wawancara dengan mahasiwa program studi PAUD, memang mereka diberikan teori-teori penting tentang perkembangan dan pertumbuhan anak, akan tetapi tidak diberikan materi praktek secara mendalam tentang belajar gerak dasar. Sedangkan berdasarkan penelitian, untuk mengembangkan kemampuan kognitif memerlukan gerak yang berkualitas agar otak dapat berkembang secara optimal. Berdasarkan permasalah ini, pengabdi yang juga merupakan tim pembelajaran gerak dasar pada Universitas Negeri Padang merasa terpanggil untuk transfer pengetahuan dan temuan sebelumnya tentang hasil dari penelitian dan observasi yang telah dilakukan.

Hasil pengamatan pelatihan-pelatihan yang pernah diselenggarakan baik pelatihan sejenis peningkatan mutu atau pelatihan berbasis keterampilan berpikir kritis untuk guru-guru PAUD lebih banyak menitik beratkan pada pemberian informasi konsep-konsep dan teori-teori saja, jarang sekali instruktur/fasilitator memberikan contoh konkret model pembelajaran setelah penyajian konsepkonsep atau teori-teori, sehingga yang diperoleh guru-guru dalam kegiatan pelatihan hanya sebatas pengetahuan semata.

Pelatihan seperti itu tidak berdampak pada kemampuan (pengetahuan dan keterampilan) guru dalam menyelenggarakan pembelajaran sains berbasis keterampilan berpikir kritis, baik pada tahap perencanaan maupun pada tahap pembelajaran di kelas. Secara umum tujuan pelatihan guru dinyatakan oleh Moekijat (1993) adalah untuk penambahan pengetahuan, keterampilan, dan perbaikan sikap dari peserta pelatihan.

Peningkatan mutu guru yang dilakukan tidak akan lepas dari peningkatan kompetensi guru dan harus sesuai dengan sistem standarisasi guru di tiap-tiap jenis dan jenjang pendidikan sekolah (satndar kompetensi). Tujuan dikembangkan standar kompetensi guru adalah untuk menetapkan suatu ukuran kemampuan pengetahuan dan keterampilan yang harus dikuasai oleh seorang guru agar profesional dalam merencanakan dan mengelola proses pembelajaran di sekolah. (Suwondo, MS: 2003).

Dengan demikian, dapat dipahami bahwa untuk meningkatkan kompetensi guru hendaknya dilakukan dengan program terecana dan terprogram sesuai tujuan yang akan dicapai, begitu juga dalam peningkatan kompetensi nguru PAUD dalam bidang merealisasikan gerak dasar kepada siswa. Melalui kegiatan pengabdian kepada masyarakat ini, pengabdi berasumsi dapat menambah dan menyebarluaskan pengetahuan yang baru kepada guru-guru di Sumatera Barat secara bertahap. Transfer pengetahuin ini pengabdilakukan dengan mengadakan kegiatan pelatihan yang terpusat pada daerah yang terpilih menjadi objek pengabdian.

Capobianco dan Lehman (2006) dalam Witarsa (2015) menerangkan bahwa pelatihan (inservice), diartikan sebagai seluruh kegiatan yang direncanakan untuk membantu guru dalam meningkatkan pengetahuan, keterampilan, dan sikap yang diperlukan dalam melakukan tugas guru dengan baik, dan menjadi tanggung jawabnya, sehingga tujuan dapat tercapai. Menurut Oumar Hamalik (2001) bahwa pendidikan dan pelatihan merupakan suatu proses yang meliputi serangkaian upaya yang dilakukan dengan sengaja dalam memberikan bantuan kepada guru/pegawai yang dilakukan secara profesional, pelatihan dalam jangka waktu yang telah ditentukan untuk meningkatkan komitmen kerja pada bidang tugas yang ditentukan.

Pelatihan yang akan pengabdi lakukan di tempat lokasi mitra merupakan langkah awal yang harus dilakukan sebelum tindak lanjut ke langkah berikutnya. Untuk memperbaiki gerak dasar anak tentunya tidak bisa dilakukan dengan memberikan program secara langsung tanpa mengetahui sejauh mana kemampuan awal dari anak tersebut. Pelatihan dalam mengevaluasi gerak dasar menggunakan instrument TGMD ini juga akan mengungkap kemampuan dasar dan tingkatan level gerak pada masing-masing anak. Setelah mengetahui tingkatan keterampilan gerak dasar anak barulah berikutnya pengabdi akan memberikan alternative solusi yang tepat dalam mengatasinya.

\section{4 | Implementation Of Tgmd In Evaluating Basic Motion Skills




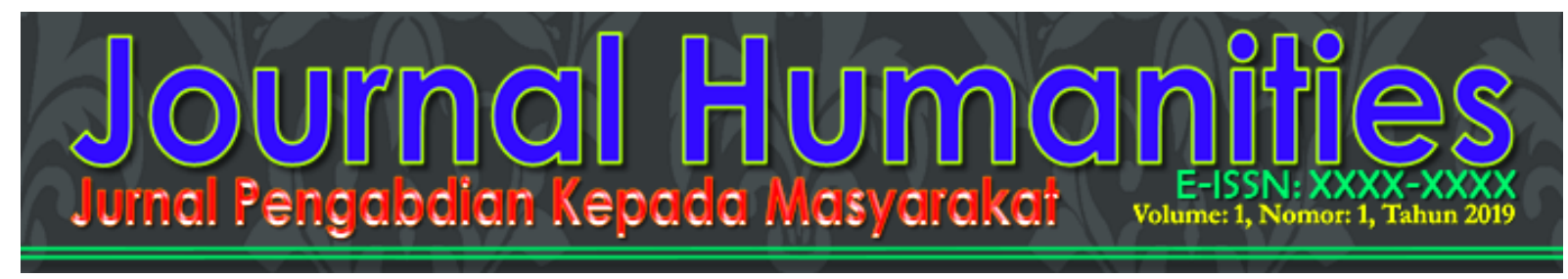

Dapat dikatakan tanpa mengevaluasi dengan mengetahui level gerak anak mustahil kita dapat memberikan solusi atau perbaikan-perbaikan terhadap anak. Dapat diartikan bahwa pelatihan mengandung makna bahwa setelah mengikuti pelatihan guru akan terdorong motivasinya untuk memperbaiki kinerja, cara pembelajaran atau penyegaran ilmu dan informasi yang diperolehnya. Pelaksanaan kegiatan pengabdian ini setidaknya dapat meningkatkan pengetahuan, dan keterampilan guru PAUD kabupaten Sijunjung dalam peningkatan penguasaan keterampilan gerak dasar yang akan ditransfer kepada anak di sekolah-sekolah.

Fokus kegiatan pengabdian ini adalah dalam melatih guru untuk mempraktekkan keterampilan gerak dasar, mempraktakkan dalam mengukur dan mengevaluasi gerak dasar anak menggunakan instrument test of gross motor development third edition (TGMD), merancang pembelajaran gerak dasar secara efektif dan merealisasikan di tempat tugas mereka masing-masing. Kegiatan penting yang harus dilakukan secara kontiniu adalah membangun komunikasi yang baik antara lembaga Universitas Negeri Padang (pengabdi) dan Mitra (guru PAUD Sijunjung) setelah kegiatan dilaksanakan. Hal ini bertujuan agar kegiatan yang dilakukan tidak terputus dan akan terus berlanjut baik berupa diskusi, informasi hingga transfer ilmu dan temuan baru yang penulis dapatkan melalui riset berikutnya dengan kajian yang terkait.

\section{METODE PELAKSANAAN}

Sebelum kegiatan pengabdian dilaksanakan, tim pengabdian melakukan proses observasi terlebih dahulu kepada khalayak sasaran, guna menemukan masalah yang ada pada mitra, selanjutnya pengabdi melakukan sosialisasi dengan melakukan diskusi kebeberapa sekolah menemui guru dan kepala sekolah TK/PAUD di Kabupaten Sijunjung untuk berkomunikasi dan menjelaskan tujuan dan pentingnya kegiatan pengabdian ini dilaksanakan. Kegiatan pengabdian ini dilakukan melalui:

\section{Pemberian Materi}

Pemberian materi dilakukan melalui beberapa metode kepada khalayak sasaran tentang pembelajaran gerak dasar serta instrument evaluasi gerak dasar dan penggunaannya. Diantra beberapa metode tersebut adalah: metode ceramah, demonstrasi, diskusi serta pemecahan masalah, selanjutnya pengabdi melakukan pendampingan dalam realisasi materi setelah kegiatan pelatihan dilakukan. Materi yang diberikan memuat informasi tentang : (a) Wawasan pentingnya gerak dasar bagi anak usia dini, (b) Pengetahuan dan keterampilan gerak dasar bagi guru PAUD, (c) Instrument dan cara pengukuran gerak dasar bagi guru PAUD, (d) Keterampilan dalam merancang pembelajaran gerak dasar.

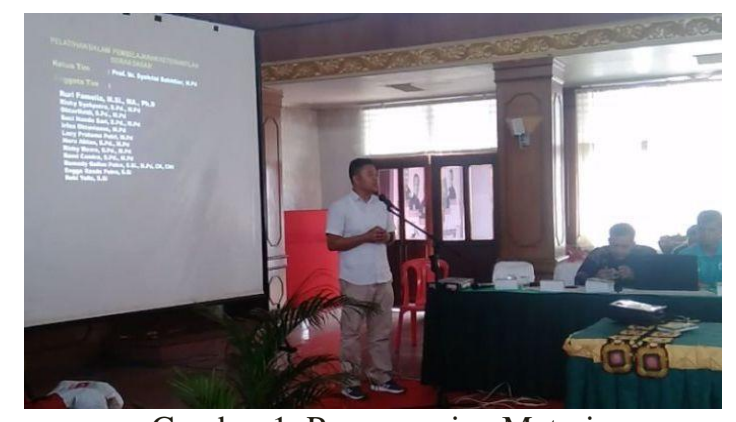

\section{Melakukan Diskusi Tentang Materi Gerak Dasar}

Diskusi ini dilakukan agar khalayak sasaran lebih memahami tentang gerak dasar. Khalayak sasaran sangat antusias dalam kegiatan diskusi ini karena mereka memiliki rasa ingin tahu yang besar tentang pentingnya gerak dasar bagi anak usia dini dan cara mengevaluasi awal kemampuan anak di TK dan PAUD.

\section{5 | Implementation Of Tgmd In Evaluating Basic Motion Skills Oktarifaldi $^{1}$, Risky Syahputra ${ }^{2}$, Hasriwandi Nur ${ }^{3}$, Willadi Rasyid ${ }^{4}$ http://jha.ppj.unp.ac.id}



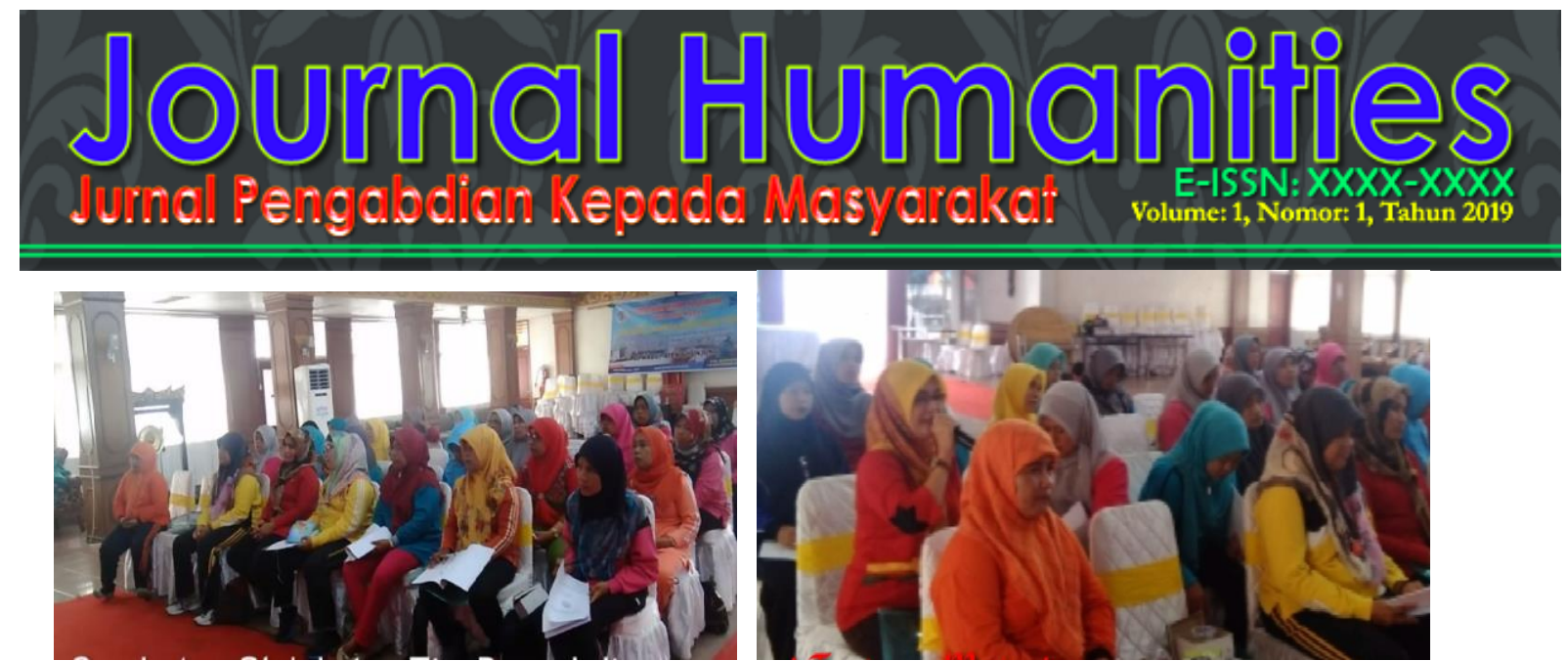

Gambar 2. Diskusi Tentang Materi Gerak Dasar Anak Gambar 3. Diskusi Tentang Materi Evaluasi Gerak Usia Dini Dasar

\section{3. Melakukan Praktek Pembelajaran Gerak Dasar}

Setelah meteri disampaikan dan dilanjutkan dengan diskusi berkenaan dengan substansi, sesi selanjutnya dilakukan praktek pembelajaran gerak dasar bagi masing-masing guru agar transfer pengetahuan benar-benar diserap dan dikuasai dengan baik.

Selanjutnya praktek ini bertujuan untuk mendalami dan mengetahui secara ril proses pembelajaran gerak dasar dan proses evaluasi yang akan direalisasikan guru terhadap anak di TK dan PAUD. Dalam pembelajaran dikenal dengan urutan yang dimulai dari yang mudah sampai yang agak sukar, begitu juga dalam memilih materi yang sesuai dan selaras dengan tujuan yang akan dicapai.

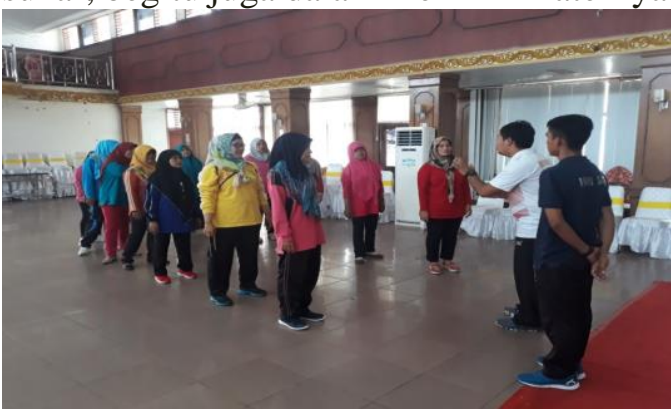

Gambar 4. Demonstrasi Gerak Lokomotor

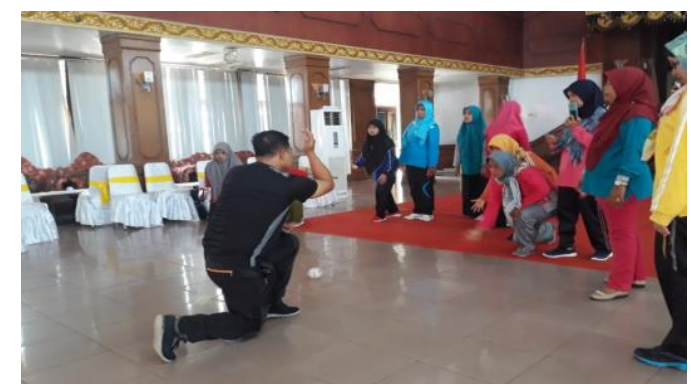

Gambar 6. Demonstrasi Gerak Objek Kontrol

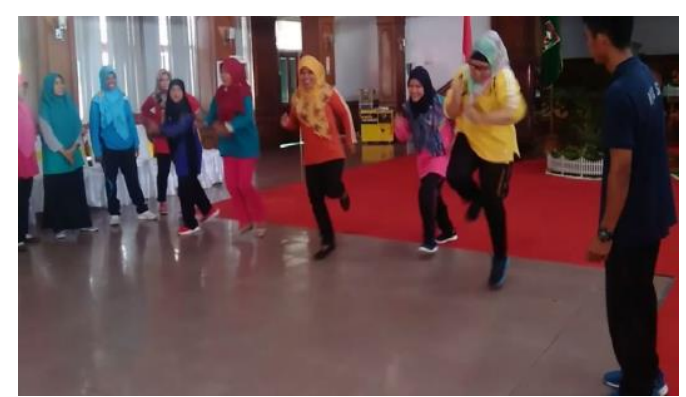

Gambar 5. Guru Mempraktekkan Gerak Lokomotor

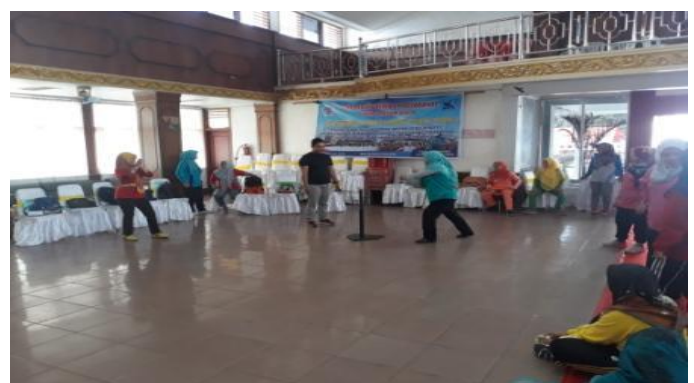

Gambar 6. Guru Mempraktekkan Gerak Objek Kontrol

\section{Merancang Pembelajaran Gerak Dasar}

Dalam merancang pembelajaran gerak dasar, guru dibimbing dalam memilih materi yang akan disampaikan. Materi yang disampaikan sesuia dengan pola gerak yang dianggap tidak terlalu rumit direalisasikan guru saat transisi dan saat praktek bagi anak. Selanjutnya dalam mempraktekkan item gerak lokomotor dan objek control pengabdi dan Tim memberikan arahan agar pembelajaran berjalan dengan efektif, baik dalam mempersiapkan kelas, media pembelajaran, memilih materi, membuka pembelajaran, menyampaikan materi inti dan penutupan pembelajaran (evaluasi).

\section{6 | Implementation Of Tgmd In Evaluating Basic Motion Skills Oktarifaldi $^{1}$, Risky Syahputra ${ }^{2}$, Hasriwandi Nur ${ }^{3}$, Ali Asmi ${ }^{4}$ http://jha.ppj.unp.ac.id}




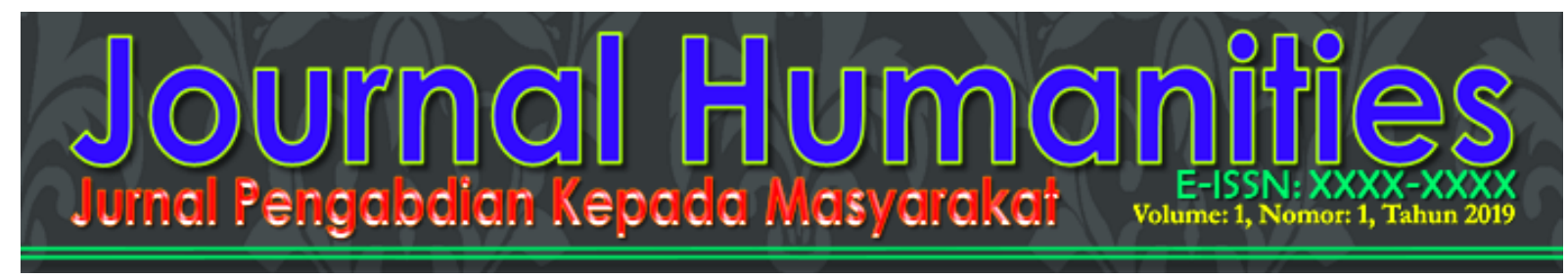

Pengabdi dan Tim memberikan masukan kepada guru agar dapat memanfaatkan waktu sefektif mungkin.

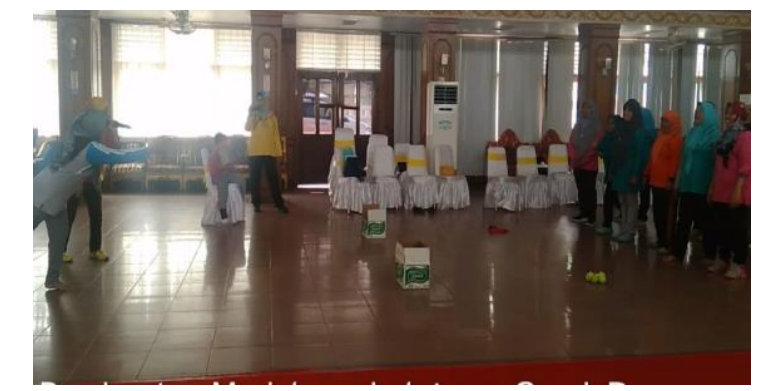

Gambar 7. Guru Mempraktekkan Pembelajaran Gerak Dasar

\section{Melakukan Pendampingan Dalam Implementasi Pembelajaran Di Sekolah}

Pengabdian melakukan kegiatan pendampingan kepada Mitra (peserta Pelatihan) dengan mengunjungi mitra 2 kali pertemuan. Kegiatan yang dilakukan adalah berupa diskusi, konsultasi serta evaluasi dalam proses pembelajaran di sekolah.

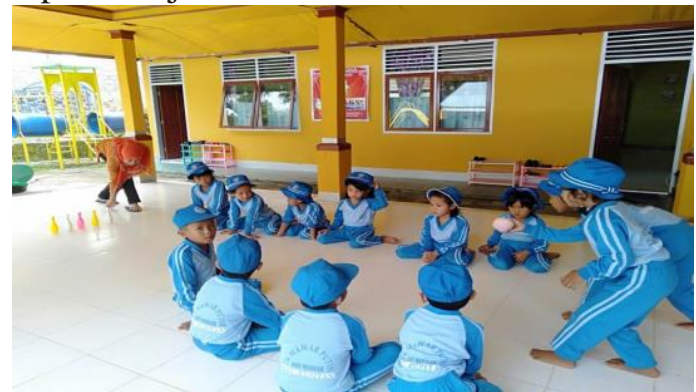

Gambar 8. Pendampingan Dalam Pembelajaran Gerak Objek Kontrol

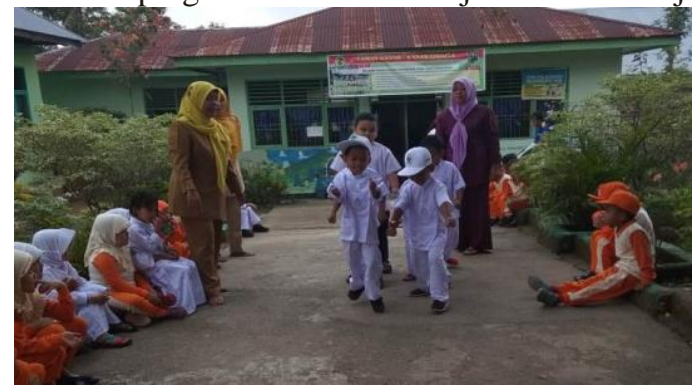

\section{HASIL DAN PEMBAHASAN}

\section{Hasil}

Pengabdian ini telah selesai dilaksanakan pada tanggal 7 samapai 8 September 2019 di gedung Pancasila Muaro Sijunjung. Kegiatan ini dihadiri oleh Kepala Seksi bidang Pendidikan Anak Usia Dini kabupaten Sijunjung, Ketua IGTKI kecamatan Koto VII dan ketua KKG TK selingkungan kecamatan Koto VII dan guru-guru TK dan PAUD se kabupaten Sijunjung yang berjumlah 40 peserta. Setelah mendapatkan wawasan, keterampilan dan pengalaman dalam pelaksanaan pembelajaran gerak dasar, kegiatan selanjutnya adalah monitoring dan pendampingan dalam mengimplementasikan materi. Hal tersebut pengabdi lakukan demi terealisasinya tujuan pengabdian kepada masyarakat secara efektif.

Rangkaian kegiatan selanjutnya adalah monitoring dan pendampingan yang pengabdi lakukan terhadap mitra. Pendampingan I dalam implementasi pembelajaran oleh mitra (guru yang ikut pelatihan) dilaksanakan pada tanggal 14 September 2019, pengabdi hadir mendampingi dan berdiskusi dengan guru tentang implementasi materi dan membentu memecahkan permasalahan yang ditemui saat penyampaian materi. Pendampingan II dilaksanakan pada tanggal 19 September 2019, hal ini terfokus pada diskusi dan perbaikan metoda yang disampaikan oleg guru sesuai dengan kondisi 


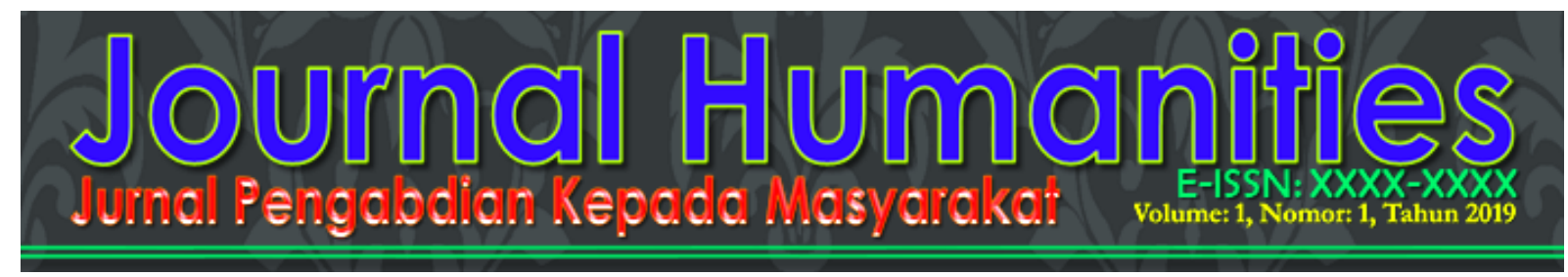

sekolah dan sarana yang dimiliki. Pengabdi dan mitra juga berdiskusi tentang hal-hal yang dianggap perlu untuk kelanjutan kegiatan dan membangun komunikasi dengan mitra secara kontiniu.

\section{Pembahasan}

\section{Keterampilan Dasar Anak Usia Dini}

Goodway dalam Sciencedaily (2010) menyatakan "banyak orang bahkan tenaga pendidik meyakini bahwa keterampilan gerak dasar berkembang secara alami, namun banyak studi yang kami lakukaan menunjukkan tidaklah demikian."Selama tahun-tahun sebelum memasuki sekolah dan masa sekolah dasar, kemampuan motorik (gerak) seorang anak mulai muncul dan berkembang. Perkembangan fisik dan pengalaman gerakan dari sejarah seorang anak memainkan peranan penting dalam mempengaruhi pemerolehan dalam pola gerak. Jika kekurangan-kekurangan dalam perkembangan gerak dasar tidak dikenali dan diperbaiki, anak-anak akan mengalami masalah-masalah yang menetap dengan keterampilan gerak dikemudian hari.

Mengingat pertumbuhan dan perkembangan otak terjadi pada usia 3-6 tahun, maka perlakuan untuk meningkatkan keterampilan kognitif anak perlu diterapkan dengan seksama. Penelitian sejumlah ahli (Chisholm et al., 1995; Chugani, 1996; Ramey \& Ramey, 1994; Singer, 1995) memperlihatkan bahwa ukuran, kompleksitas dan synapsis pada otak anak akan tumbuh seiring dengan peningkatan kuantitas dan kualitas pengalaman sensori saat beraktifitas fisik.

Fakta ini menegaskan bahwa tidak hanya lama anak bermain yang harus ditingkatkan, namun kualitas dalam permainan juga harus diperhatikan. Perkembangan gerak dasar menurut Ulrich (2000) sering diabaikan oleh para pendidik pada awal masa kanak-kanak. Goodway dalam Sciencedaily (2010) menyatakan "banyak orang bahkan tenaga pendidik meyakini bahwa keterampilan gerak dasar berkembang secara alami, namun banyak studi yang kami lakukaan menunjukkan tidaklah demikian."

Selama tahun-tahun sebelum memasuki sekolah dan masa sekolah dasar, kemampuan motorik (gerak) seorang anak mulai muncul dan berkembang. Perkembangan fisik dan pengalaman gerakan dari sejarah seorang anak memainkan peranan penting dalam mempengaruhi pemerolehan dalam pola gerak. Dalam proses belajar gerak untuk anak usia sekolah dasar menurut Corbin (1980) adalah peletakan penguasaan berbagai gerak dasar. aktivitas tubuh yang membentuk gerak dasar menurut Laban dalam Syahrial (2015) dapat diklasifikasikan dalam tiga kategori yaitu : (a) Aktifitas lokomotor, aktivitas yang menyebabkan tubuh berpindah dari satu tempat ke tempat lain, (b) Aktifitas non lokomotor, aktivitas yang apat dilakukan tanpa harus berpindah tempat berpijak, atau tanpa maksud berpindah ke tempat lainnya, (c) Aktivitas manipulasi, aktivitas yang digunakan untuk menipulasi atau menghindari alat.

TKGD merupakan tes yang digunakan untuk mengevaluasi kemampuan gerak dasar individu, khususnya anak usia 3 hingga 10 tahun. Tujuan dari TKGD, yaitu: (a) Mengidentifikasi keterlambatan perkembangan keterampilan gerak dasar pada anak, (b) Merencanakan program instruksional untuk pengembangan keterampilan gerak dasar, (c) Menilai kemajuan perkembangan keterampilan gerak dasar individu, (d) Mengevaluasi keberhasilan program keterampilan gerak dasar, (e) Sebagai instrument pengukuran dalam penelitian yang berhubungan dengan perkembangan gerak dasar. Material dan perlengkapan yang diperlukan untuk melaksanakan TKGD terdiri atas lembaran manual bagi penguji, lembaran untuk mencatat hasil tes dan beberapa alat adalah: (1) Bola karet dengan diameter $20-25 \mathrm{~cm}$, (2) Bola plastik ringan dengan diameter $10 \mathrm{~cm}$, (3) Bola plastik/busa diameter 7 $-8 \mathrm{~cm}$, (4) Bola basket, (5) Bola tenis, (6) Bola kaki, (7) Beanbag bujur sangkar ukuran $10-12 \mathrm{~cm}$, (8) Tongkat pemukul berbahan plastik, (9) Kerucut pendek (half cones), (10) Tiang tempat bola (batting tee), (11) Penanda lantai (kapur, atau lakban, atau polyspots).

Dalam pelaksanaan tes TKGD setiap anak memerlukan waktu sekitar 15-20 menit. Selain itu diperlukan waktu tambahan untuk persiapan dan pembersihan alat sekitar 10 menit. Agar waktu pelaksanaan tes berjalan optimal, sediakan alat dalam jumlah yang cukup, misalnya bola dan pemukul, lalu kondisikan anak beralih dari satu tes ke tes lain dengan cepat. Biasanya hanya diperlukan satu sesi saja untuk melaksanakan seluruh tes tapi untuk membiasakan anak dengan lingkungan maka berikanlah beberapa sesi agar evaluasi menjadi lebih optimal

\section{8 | Implementation Of Tgmd In Evaluating Basic Motion Skills Oktarifaldi $^{1}$, Risky Syahputra ${ }^{2}$, Hasriwandi Nur ${ }^{3}$, Ali Asmi ${ }^{4}$ http://jha.ppj.unp.ac.id}




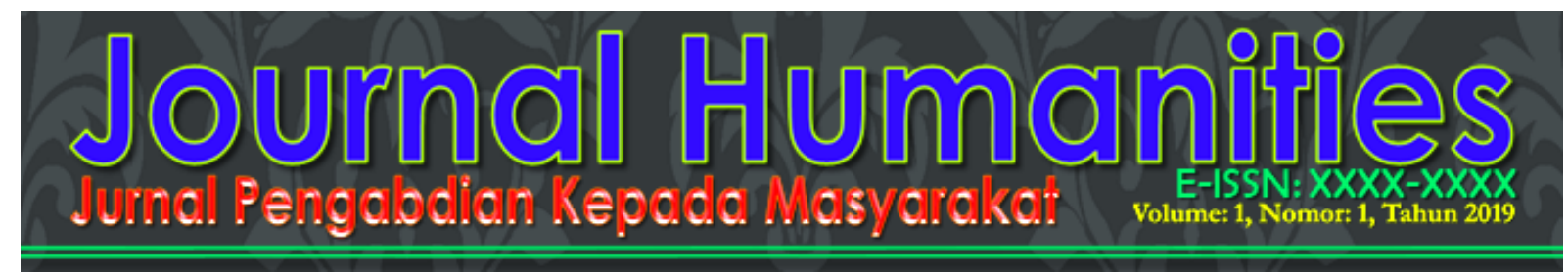

\section{KESIMPULAN}

Berdasarkan kegiatan Pengabdian Kepada Masyarakat yang sudah dilaksanakan di Kabupaten sijunjung, dapat disimpulkan sebagai berikut:

1. Pelaksanaan Kegiatan Pengabdian Kepada Masyarakat ini telah berhasil dilaksanakan dengan baik tanpa mengalami kendala yang berarti.

2. Kegiatan Kegiatan Pengabdian Kepada Masyarakat ini memberikan edukasi bermanfaat kepada masyarakat (guru, orang tua, peserta didik) Kabupaten Sijunjung mengenai defenisi, pemahaman dan wawasan mengenai pembelajaran keterampilan gerak dasar anak usia dini bagi guru PAUD di Kabupaten Sijunjung.

3. Kegiatan Pengabdian Kepada Masyarakat ini memberikan gambaran dan fakta yang terjadi secara umum mengenai kemampuan anak serta pentingnya pembelajaran gerak dasar anak usia dini.

4. Kegiatan ini secara keseluruhan telah memberikan pengetahuan dan pengalaman bagi guru dalam mendemonstrasikan serta merancang pembelajaran gerak dasar anak usia dini kepada mitra (guruguru PAUD). Selanjutnya guru PAUD di Kabupaten Sijunjung telah memiliki pengalaman dan keterampilan dalam mengevaluasi gerak dasar anak.

\section{DAFTAR PUSTAKA}

Clark JE, Metcalfe JS. (2002). The mountain of motor development.In: Clark JE, Humprehy JH, editors. Motor development:research and reviews. Vol. 2. Reston (VA): National As-sociation of Sport \&Physical Education

S. Bakhtiar, \& R. Famelia. (2017) . Institute Role of Teachers' Education in Improving the Standard of Development Achievement Rate and Standard of Teacher and Education Personnels of Early Childhood Education. International Conference of Early Childhood Education (ICECE 2017). Advances in Social Science, Education and Humanities Research (ASSEHR), volume 169

Ulrich, D.A. (2000). The Test of Motor Development (Second ed). Austin: TX Pro-ed

Canchild. 2010. Form pemeriksaan GMFM. Canada : Institute for Applied Health Sciences, McMaster University.

Gusril, (2015). Perkembangan motorik pada masa anak-anak. Padang : UNP Press

Gallahue, David L; Ozmund, Jhon. C; Goodway, Jaqueline D. (2012). Understanding Motor Development, Infact, Children, Adolecents, Adults, Seventh Edition. New York: Mc Graw Hill.

Moekijat. 1993. Teori Komunikasi. Bandung : Mandar Maju.

Suwondo, MS. (2003). Guru di Indonesia. Jakarta: Dittendik Dirjen Dikdasmen

Witarsa, Ramdhan. (2015). Pengembangan Program Pelatihan Untuk Meningkatkan Kompetensi Guru Dalam Memfasilitasi Keterampilan Berpikir Kritis Anak Usia Dini. Tunas SiliwangiVol.1 | No.1 Oktober 2015.

Hamalik, Oemar. (2001). Proses Belajar Mengajar. Jakarta: Bumi Aksara.

Syahrial, Bakhtiar (2015). Perancang pembelajaran gerak dasar anak. Padang : UNP PRESS.

Ramey, C. T. \& Ramey, S. L. (1994). Which children benefit the most from early intervention? Pediatrics, 94, 1064-1066. 